\title{
Deep Sea Tension: The Kingdom of Tonga and Deep Sea Minerals
}

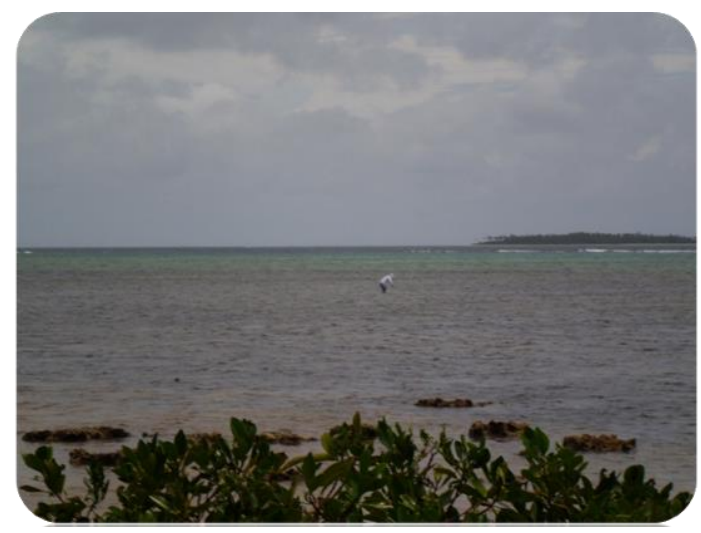

\section{Abstract}

The Kingdom of Tonga was quick off the mark sponsoring deep sea mining companies for exploration licenses to the International Seabed Authority. On the 11-15 March 2013 a regional workshop on deep sea minerals facilitated by the Secretariat for the Pacific Community was held in Nuku'alofa, Tonga. Fifteen Pacific Island states attended. It was focused on state law and regulations, and enforcing compliances for safe mining and liability for seabed damage on the mining companies. Tonga's bill reading for a deep sea minerals act was scheduled for parliament in August 2013, but in the meantime, the state permitted companies to explore without the legislative framework. In contrast to Melanesian states, the Kingdom of Tonga and deep sea minerals had not awoken an organised anti-mining movement from civil society and the general public. Why was that? And did this mean that 
Tonga's experiences in a frontier commercial industry might travel a different course of development?

\section{What's in a workshop?}

If you don't like someone else's story, write your own.

\section{Chinua Achebe}

A Tongan government official from the Ministry of Lands and Environment chaired the panel of mining companies and lawyers which concluded the regional workshop for deep sea minerals on Friday afternoon of March the 15th, 2013. The Secretariat of the Pacific Community (SPC), an intergovernment organisation based in Fiji servicing 22 Pacific Island member states had an applied geoscience and technology division (SOPAC). SOPAC housed a Deep Sea Minerals Project, a collaboration between the Secretariat of the Pacific Community (SPC) and the European Union (EU). The SPC-EU Deep Sea Minerals Project organised this five day event from 11-15 March 2013 in Nuku'alofa, Tonga, the second workshop in a series of five aimed at developing regional legislation and regulations for seabed mining (Menzies, 2013).

The entire workshop exercise was oriented in a role play. Foremost, attendants were put into teams not of their choosing that represented the three stakeholder groups. First, the government of an imaginary country called Tongolia which rhymes with Mongolia; second, a mining company, and third, a civil society organisation. From there, the Pacific Islanders were given a scenario and made to negotiate their terms of contract to explore and exploit deep sea minerals from their side of the talk table. Presentations and panel discussions by mining companies, lawyers, and geologists were intended to inform the scenario building practice of workshop participants. Four years of European Union (EU) funding due to run out in 2014 had financed SOPAC's Deep Sea Minerals Project to ready the Pacific region for contracts and companies. And this is what the EU's gifted Euros motivated by the anticipated millions to be made from deep sea minerals boiled down to; arming the country of Tongolia to go aggressively at the company for the best deal. 
The SOPAC director and the legal advisor to the Deep Sea Minerals Project were both British. Perceptibly the Secretariat appointed imported labour from the United Kingdom (UK) as the management given that the EU bankrolled the Pacific Island model. For the Nuku'alofa workshop SOPAC brought in an American lawyer to facilitate the Tongolia role play, a specialist in commercial mining contracts. In a coconut shell, Europe and North America determined the method for how small island developing states would rationalise and carry out the work of getting overseas companies to mine the sea floor for remuneration by licencing fees and royalty cheques. Theoretically, if quality minerals were brought up from the bottom of the ocean, Pacific Island states could make money beyond their lived experience to alleviate poverty in their countries, as opposed to living on the benefit by way of sole dependence on aid donors.

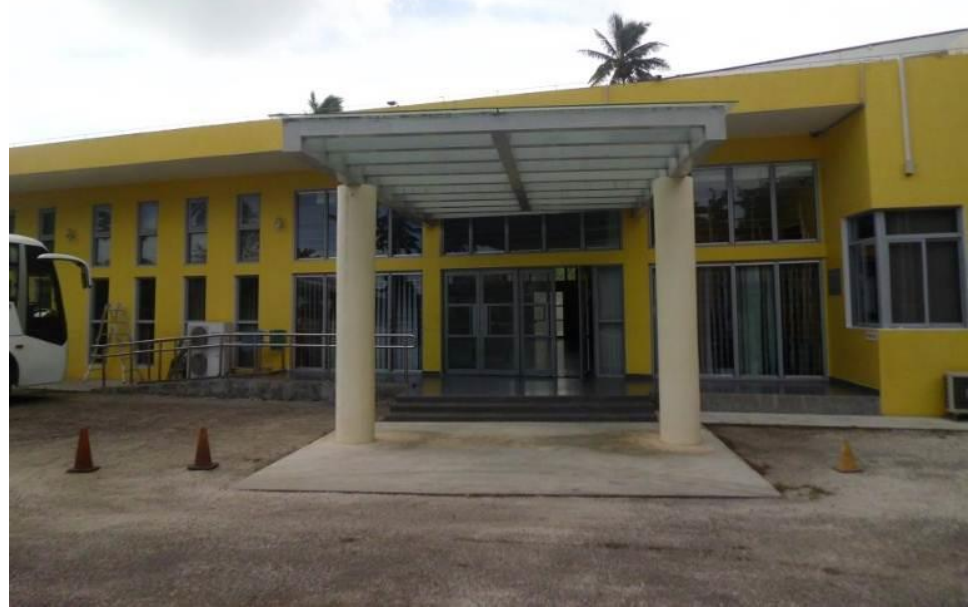

The venue of the 2nd SPC-EU regional workshop on deep sea minerals, 11-15 March 2013, Fa'onelua National Convention Centre, Nuku'alofa, Kingdom of Tonga.

Nuku'alofa this Friday afternoon sweltered in humidity recovering from rain storms that had flooded the capital, an impact indicator that climate change was here. Fifteen Pacific 
Island states were in attendance weary from role playing a week long scenario devised by foreigners for South Seas digestion, but eager none-the-less to engage in the open floor question and answer time.

From the chair's seat, the government official announced that all of Tonga's tenement leases for exploration were used by three mining companies from Canada, Korea, and Australia. The Tongan state was monitoring each company's performance and considering how its regulatory regime could move out under-performing companies so that a better company could move in to do the work. This was all underway without a law for seabed mining in their country. The law, the regulations, the machinery of government protecting the state from liability were being circulated in the bureaucracy for comment. The bill should be arriving in parliament for its first reading around July, August, or thereabouts. Local media reported that the Attorney General hoped, fingers crossed, the Tongan public got a chance to read and comment on the bill before it landed in the House (Matangi Tonga Online, 2013).

Tonga was coined the Friendly Islands by Captain Cook in the 18 th century, a label interpreted two ways by 21 st century Tongans. The Friendly Islands was either a national identity trademark or an old blemish difficult to get rid of. Tonga was planted on the international dateline, the place where time begins. Many overseas Tongans recounted an alternative description: Tonga is the country where time comes to a dead end or moves painstakingly slow. Tonga was a small poor country of 104 thousand people, a state where Australian and New Zealand ex-patriates, older white men, occupied highlevel state bureaucracy jobs over the Tongans born in this country. 


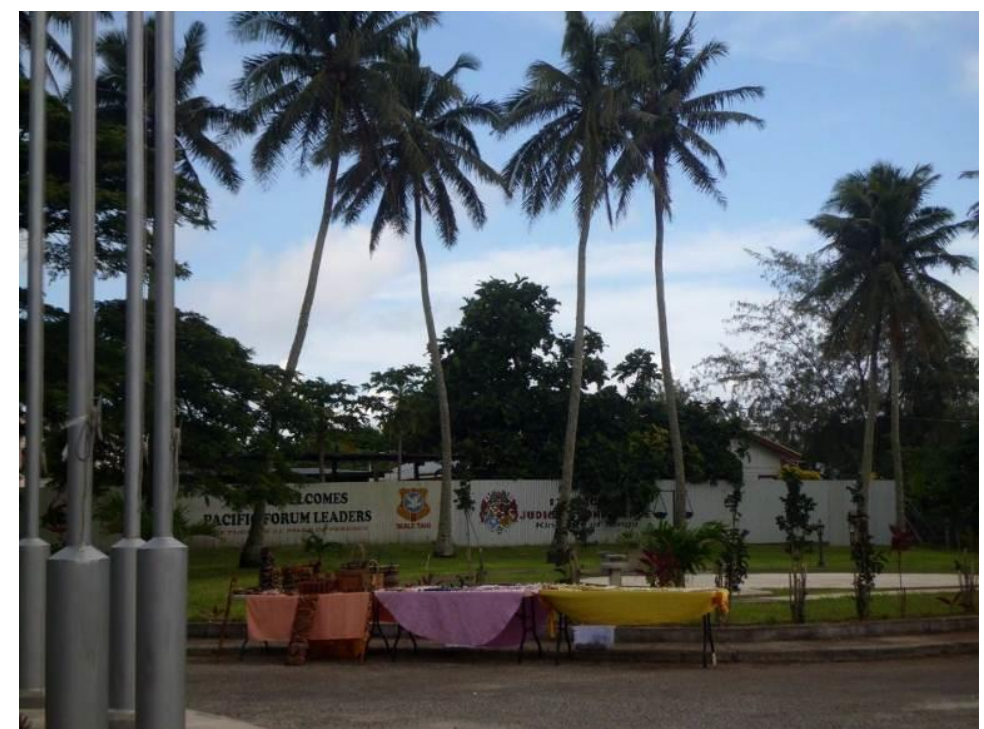

An unattended table of handcrafts sold by local women outside the Fa'onelua National Convention Centre at the 2nd SPC-EU regional workshop on deep sea minerals, 11-15 March 2013, Nuku'alofa, Kingdom of Tonga.

This scenario played out in real life when I noticed the Attorney General of Tonga walk in late to the final workshop panel while in session. He was an older white man with grey hair wearing a Tongan ta'ovala. To me, he looked peculiar as if he were trying very hard to imitate someone he was not; that is, a brown-skinned Tongan man of traditional rank and status dressed in a hand-woven pandanus mat with coconut frond rope holding it up. The concentration lines on his face hardened into a frown when soaking in the Tongan government official's remarks.

Witnessing how the discussion of one Tongan male bureaucrat had turned the facial expression of an older white man in a position of state power and authority, signalled there was tension in empire. The logic around how the mechanisms in the deep sea minerals act policed mining companies and held them to account, obviously varied between individuals and the ministries they worked in.

My ancestral homeland in the Pacific Ocean, Tonga, is an origin place which wins at stirring my colonial history of family 
attachment. Tracing myself to half-caste, part Tongan, part Palangi roots, I am the granddaughter of a British administrator and his Native Tongan wife - my maternal grandparents. Persistently the New Zealand media has captured Tonga as the South Pacific Kingdom failing at doing democratic reform, without paying attention to how the authority of patriarchal tradition and hierarchical culture is positioned directly at odds with the political arrangement. And here was this coral island Kingdom headed straight into the frontier industry of deep sea mineral exploration and exploitation.

SOPAC's legal advisor named and framed this new commercial industry by a simplistic analysis; "an exciting development" for the Pacific Islands. These small island states in the world's largest ocean were imagined to be developing, evolving, transforming into the image and likeness of developed countries, cultures, and consciousness (Ministry of Information and Communications, 2013). By reproducing the ideals of the West, a sinister aftermath prevailed. Pacific Island states were willing to be made into a second-class caricature of developed countries, and be stripped of their small society distinctiveness.

Nigerian writer, Chinua Achebe, identified the problem of restricting the vision of non-Western countries so they view the world through lenses not of their own making. "For societies that abandon themselves," Achebe predicted an unhealthy result that exacerbates social and economic inequality by privileging "American ideas, culture, and behaviour" as the single pathway for development (Bacon, 2000).

That's a real problem. The mindless absorption of American ideas, culture, and behavior around the world is not going to help this balance of stories, and it's not going to help the world, either. People are limiting themselves to one view of the world that comes from somewhere else. That's something that we have to battle with as we go along, both as writers and as citizens. I think that one can say this limiting isn't going to be very healthy for the societies that abandon themselves. (Bacon, 2000).

To be brutally honest, I attended the last Friday of the fiveday workshop carrying excess baggage, feeling guilty that I 
was not pulling my weight to raise critical awareness on development disparities in my island homeland. Saying to myself that I was observing the end of week wrap-up and evaluation as an AUT University academic and a Tongan anthropologist contended with the truth. I was not a commercial mining fan. My consciousness was coloured by my brown skin and long thick curls, the physicality of Tongan ancestry. My rationale was disciplined by my New Zealand university education; a system socialising me to be scathingly critical of European and North American research and development invading the southern hemisphere border.

In the South Pacific, postcolonial critics of colour and culture were not friendly islanders and happy Natives about being dominated and controlled by the superior wealth and resources of the North. I had grown up in the university with the South's human psyche. They could all travel back across the border with that kind of superiority complex, a relic of Western European and US imperialism in the Pacific. That was my attitude. I wore it loudly on my body language and spoke it bluntly with my pronounced Kiwi accent in English to ward off people whose patronising tone and tenor offended me.

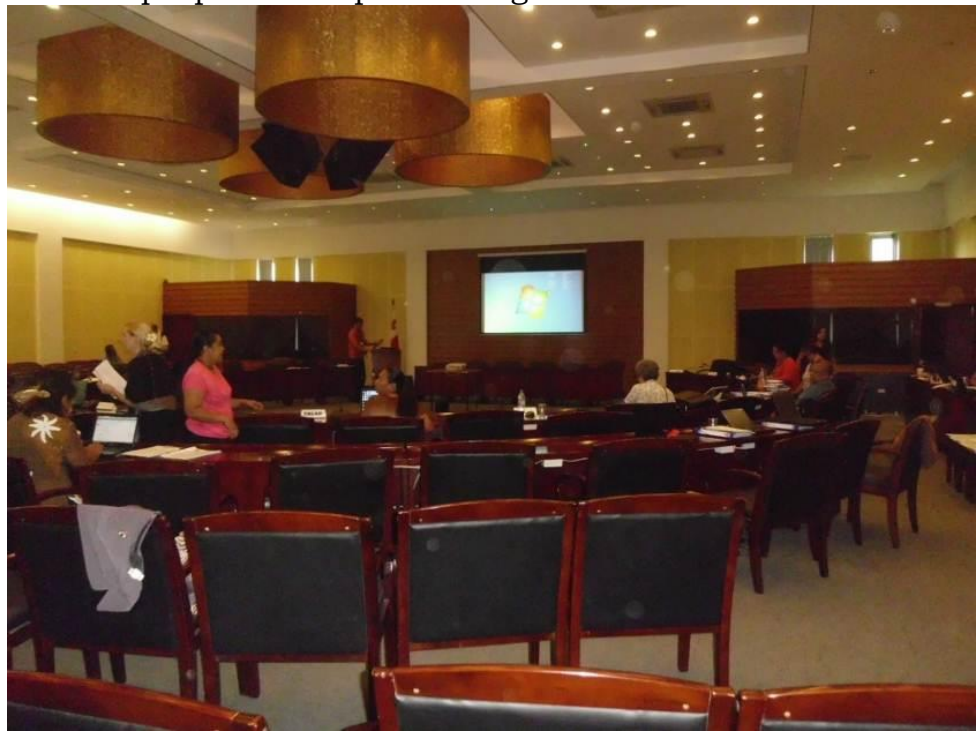

The set-up inside Fa'onelua National Convention Centre for the 2nd SPC-EU regional workshop on deep sea minerals, 11-15 March 2013, Nuku'alofa, Kingdom of Tonga. 
Fleetingly, I was caught in what felt like The Twilight Zone, an American science fiction television series renowned for its twisted and morbid storyline. Snared in the South at a regional workshop supervised by the North, this was an official Secretariat of the Pacific Community (SPC) forum where the Pacific Islander attendants were not given an opportunity to formally evaluate the performance of the white facilitators as part of the programme.

To repeat, there was no formal and anonymous evaluation process in which participants could comment on the teaching delivery, learning experience, and pedagogical design of the five regional workshops. Of practical use to SPC and its membership of 22 Pacific Island states is gathering evaluative insights on how SOPAC's training might be improved to meet country-specific learning needs. How are participants equipped with skills contextually relevant to their homeland states? Present were fifteen heterogeneous Pacific Island countries all at markedly different stages of developing deep sea minerals legislation and regulations. Why would SOPAC use a one-size-fits-all training model bereft of historical facts from Pacific case studies in deep sea minerals to inform the workshop's role play and scenario exercise?

Unpleasantly, providing a safe way to speak back to power, to reshape the workshop design, its delivery, without being found out, without being singled out as dissident, did not figure. My annoyance at the expectation that islanders get what they are spoon-fed and should be grateful for the free funded experience, despite whether the learning and teaching was good or bad, got switched up high. 


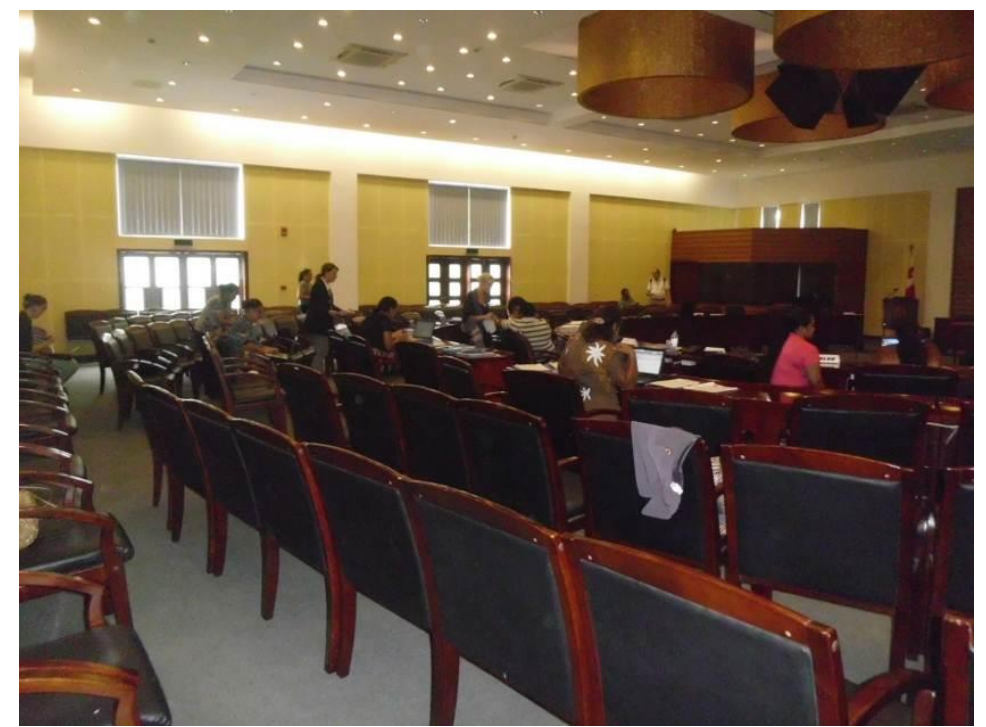

The morning break of Friday's session at the 2nd SPC-EU regional workshop on deep sea minerals, Fa'onelua National Convention Centre, 11-15 March 2013, Nuku'alofa, Kingdom of Tonga.

\section{Power and knowledge}

There were two significant lessons I took back to Auckland from the one day spent in Nuku'alofa. First, seeing the method by which Pacific Islanders of my own colour and kind were trained by two white female lawyers to negotiate mining contracts for their homeland states with foreign-owned companies, exemplified Michel Foucault's critique of power and knowledge (Foucault, 1972, 1973, 1980).

Put simply, Foucault argued that power manufactures knowledge, and that the application of knowledge produces truth (Hall, 1997). However, there is a "regime of truth" at work in society whereby the kinds of truth fashioned by the dominant power hold status over and about all other kinds (Foucault, 1980, p. 131). Thus, it is the power structure and the people who assume power at the top of any given society which authorise, control, and standardise the production of what becomes predominantly taken as truth. 
Foucault explained that truth is a consequence of the system of power which polices and limits who is permitted to "say what counts as true" (Foucault, 1980, p. 131). In the regional workshop setting, the SOPAC organising body and the key facilitators, a British lawyer and an American lawyer, established themselves over and above the Pacific Islander participants as the experts on deep sea mineral legislation and contracts. They owned and represented the knowledge hierarchy. The islanders were there to acquire their knowledge to apply to their own circumstances.

There was an immediate effect from this power and knowledge relationship where the minority dominated the information exchange and the majority were its subordinate recipients. An uncritical and inequitable learning environment was constructed in which the majority of people were proscribed from contesting the "general politics of truth" (Foucault, 1980, p. 131). By this, I mean that the experts, the outsiders, were afforded the highest status to decide what information about the subject is true compared to what is false. To challenge the facilitator's authority over "what counts as true" would have proved difficult, if not impossible (Foucault, 1980, p. 131). The risk is that one might be outed from the insular circle of in-house Pacific Islanders invited by the organising body to sit obediently inside the knowledge hierarchy, but always positioned under the real experts and power brokers from outside the region.

Truth isn't outside power. Truth is a thing of this world; it is produced only by virtue of multiple forms of constraint. And it induces regular effects of power. Each society has its regime of truth, its 'general politics' of truth; that is, the types of discourse which it accepts and makes function as true, the mechanisms and instances which enable one to distinguish true and false statements, the means by which each is sanctioned ... the status of those who are charged with saying what counts as true. (Foucault, 1980, p. 131).

The second lesson I learned was that the absence of media, social critics, university researchers, and anti-mining and environmental lobbyists was a purposeful exclusion. Leaving out factions of society from the proceedings was a method of sanctioning and safeguarding the knowledge, power, and truth which the regional workshops organised by 
the SOPAC Deep Sea Minerals Project sought to contain and control.

Foucault spoke of "subjugated knowledge" as a by-product of the dominant group that assumes power in society. In this context, knowledge that contests the truth statements of an authoritative body is considered untrue. It becomes "disqualified knowledge" which is cancelled out as invalid, "naïve," and "low-ranking" by the institutional hierarchy.

I believe that by subjugated knowledges one should understand something else, something which in a sense is altogether different, namely, a whole set of knowledges that have been disqualified as inadequate to their task or insufficiently elaborated: naïve knowledges, located low down the hierarchy, beneath the required level of cognition or scientificity. I also believe that it is through the re-emergence of these lowranking knowledges, these unqualified even directly disqualified knowledges ... a particular, local, regional knowledge, a differential knowledge incapable of unanimity and which owes its force only to the harshness with which is it opposed by everything surrounding it - that it is through the re-appearance of this knowledge, of these local popular knowledges, these disqualified knowledges that criticism performs its work. (Foucault, 1980, p. 82).

In the regional workshop setting, the media and environmental lobbyists were two social groups seen to have troubled the truth being prescribed and disseminated by the SOPAC organising body. The American lawyer invited as an international expert on how to negotiate mining contracts gave her advice: governments and companies needed a media strategy for "controlling" the media. Although there were handpicked members from civil society organisations included in the role play and scenario exercise, their political desire was to be present on the talk table when their governments negotiated contracts with mining companies.

On the Friday workshop session in Nuku'alofa, the chosen civil society representatives were cooperative, engaged, and amicable towards the model under which governments organise licenses for deep sea mineral exploration and exploitation. Given a role in the scenario building exercise, they appeared complacent with the process. Conversely, 
environmental activists were excluded from entry and participation. Silencing their interests evidently shaped the blinkeredness of the panel discussion between mining companies, lawyers, and Pacific Islander workshop participants. The vital question to ask is how are government negotiators expertly trained without exposing them to criticism, a systematic critique of the industry, its players, and the role of the state?

To emphasise my point, Chinua Achebe outlined the fundamental importance of social inclusion in allowing diverse peoples and different viewpoints to be expressed and considered by state authorities. Expressly, his sentiments are relevant to developing laws and policies intended to strengthen the economic capacity and political systems of Third World countries and regions. Woven into my consciousness, Achebe makes clear that "if you only hear one side of the story, you have no understanding at all" (Bacon, 2000).

But the bigger story of how these various accounts tie in, one with the other, is only now becoming clear. We realize and recognize that it's not just colonized people whose stories have been suppressed, but a whole range of people across the globe who have not spoken. It's not because they don't have something to say, it simply has to do with the division of power, because storytelling has to do with power. Those who win tell the story; those who are defeated are not heard. But that has to change. It's in the interest of everybody, including the winners, to know that there's another story. If you only hear one side of the story, you have no understanding at all. (Bacon, 2000).

By constructing activism as a premeditated threat, institutional bias smothers crucial dialogue. Voices that are central to understanding the scale of impact on small island societies are prohibited for disagreeing in principle with the state for pursuing deep sea mineral mining. There is a sharp political contradiction at work. The Secretariat of the Pacific Community (SPC), the region's inter-government organisation in collaboration with the European Union (EU), advocates that transparent democratic processes drive good governance and publicly accountable decision-making. Beneath this writhes the exclusionary measures used to keep out certain groups from reviewing and decelerating the contract negotiations 
between Pacific Island states and mining companies, which in effect, undermine democracy in weak states.

It is wrong to assume that Pacific Island governments are so naïve they do not see the co-dependent business relationship between aid donors and mining companies actively pursuing economic development in their countries. The query is development for whom; who profits the most? Spike Boydell frankly pointed out on Radio Australia that mining companies which run Australia's industry replicate the same business operation in the Pacific Islands, not to overlook that AusAID funds sustainable mining in the Pacific region (AusAID, 2011). Perceptibly, this political arrangement is aimed to favour the expansion of Australian mining companies throughout the region.

Boydell's concern centred around rights of customary ownership of the seabed. He queried how and when the ideological shift will occur where Pacific Island states no longer do country-to-country business as aid scroungers, but start to think, behave, and mobilise like resource-wealthy countries.

There is a lot of pressure from mining investors, from China, from Australia, competing with these countries. And we're moving into realms of money which is relatively mindboggling to these governments. ...So what's important is the mining companies who dominate the political landscape in a country like Australia are attempting to do likewise in these Pacific countries. ...But in the Pacific there's been a reliance on donor funding and that ties in with this notion of sustainable mining support by AusAID and others. But, a hand out mentality is inappropriate when a country is sitting on billions of dollars of mineral resources. (Ewart, 2013).

Boydell's discussion makes a Eurocentric assumption revealing more about his view of how progress should, in theory, take place than it does about the Pacific Islanders he speaks of. In this sense, he supposes that switching from a "hand out mentality" to thinking as a mineral wealthy state is a reasonable expectation. How would a transition realistically happen overnight? The engagement of Pacific Island states in the deep sea minerals industry is in its infancy. This is compounded by the fact that the exploration expenses of companies cost more than the value of the extracted minerals. 
With no discoveries of large mineral deposits and cash in hand, how does "mentality" become transformed into something it is not in actuality?

When Akuila Tawake, the manager of SOPAC's Deep Sea Minerals Project remarked that "we invite all levels of stakeholders including community leaders and NGOs" to consultation workshops, this did not necessarily mean that the regional workshops were consultation driven or that environmental activists were selected as "community leaders and NGOs" (Ministry of Information and Communications, 2013). As Foucault commented, "multiple forms of constraint" come into play when producing the official truth about new development industries in poor countries considered high-risk and environmentally harmful (Foucault, 1980, p. 131). Danger is downplayed by using the language of international law to dismiss that it exists at the level of immediacy and urgency which the powerless, the excluded "community leaders and NGOs" propose.

The legal advisor to SOPAC's Deep Sea Minerals Project was certain that the International Seabed Authority's (ISA) "precautionary principle," meaning to proceed with caution, guaranteed some kind of "safe until proven dangerous" framework under which Pacific Island states could develop legislation and regulations. This mitigation legality, however, did not rule out uncertainty. It was not a measure for eliminating the unknown danger of environmental damage caused by mining the ocean floor. Neither did it gloss over the imminent harm inflicted on weak democratic states in the Pacific region when certain individuals and groups are prohibited from having a fair say on the decision making table.

The commentary of my American-Tongan colleague hit home to me what the agenda of SOPAC's Deep Sea Minerals Project entailed.

Civil society, NGOs, don't get angry much. They are so busy implementing social services. When they do get angry it is because a donor has allowed them to get angry. (Howard-Tokolahi, 2013).

By no means was this an objective and disinterested process. What unfolds is a politically motivated model tailored to assimilate the Pacific Island states into the global regime of how seabed mining is carried out according to International Seabed Authority convention dominated by the USA and its 
Western European allies. The reality is that incorporation in the global hierarchy sways the mind-set and development prospects of Pacific Island states by defined structures and processes.

Compliance with the hegemony has practical results for Pacific Island states. They become subservient, easily coerced, contained, and controlled. They remain lowly placed in world governance. They develop a long-term dependence on the expertise, training, advice, and aid of foreigners. But mostly, they are indoctrinated to believe there is no intellectual or financial advantage in fighting for national and regional distinctiveness; an outside-the-box approach purposely built for small societies to consider and engage in the enormity, the complexity, of deep sea minerals as a new development industry.

This predicament was not novel to the South Pacific region. If anything, it represented "subjugated knowledge" (Foucault, 1980, p. 82); that is, the development legacy of small island developing states. Deep sea mineral mining was experimental and high-risk development trialled in the ocean of Third World countries. It provided a storyboard for world order. It spoke to the experience of being categorised and counted as small in number and landmass, monetarily poor, vulnerable, isolated, non-Western people of colour and culture. It pointed at developing countries who were subject to the structural constraints of a global economy; people without power locked down in an integrated financial system where governments and inter-government organisations are tied to multinational corporations and international conventions to prop up state income.

\section{Mining inequality}

When I was an undergraduate university student in the 1990 s I learned that Panguna was an open-pit land mine on the island of Bougainville, north of the Solomon Islands. Panguna had been operated by an Australian company Bougainville Copper Limited, and authorised under Papua New Guinea as part of its country territory and the largest revenue earner for the state. The mine ignited Bougainville Island into a nine year civil war for independence from Papua New Guinea and a complex reconciliation process. An estimated twenty thousand people lost their lives in the conflict. Twenty thousand was half the population of Nuku'alofa and its urban 
suburbs, my hometown in Tonga. Death coupled with grief of that magnitude in a small island developing state does not recuperate, recover, and regain its former self, but rather, leaves a country lastingly scarred, changed, and haemorrhaging from social fracture.

If commercial land mining for copper in the 1990s proved to be politically destabilising in Melanesia, a regional lesson in how economic development at the corporate level can collide into local landowners and weak state government, then deep sea minerals in the 21 st century is more complex. During the month of June 2012, the Solwara Project 1 in Papua New Guinea's (PNG) Bismarck Sea unravelled into a legal dispute over the intellectual property of its seafloor production system and the government's buy-in of $30 \%$ equity shares. The PNG state and the deep sea mining company, Nautilus Minerals Incorporated, staged a stand-off bringing the company to a standstill. After failed talks with state officials and no resolution between parties, the company announced that "Nautilus have decided to terminate construction of its Seafloor Production System." Termination for Nautilus amounted to money loss, making 60 jobs redundant in PNG, "discontinuing discussions [on] an alternative vessel and associated funding solution" for the Solwara 1 Project, and a general hike in the company's operation costs for investors (Nautilus Minerals, 2012).

But all was not lost in the ocean. Nautilus Minerals CEO, Mike Johnston, was optimistic that the company would achieve "its objective of developing the world's first commercial seafloor copper-gold project and launching the deep water seafloor resource production industry, whilst maintaining an environmentally and socially responsible approach" (Nautilus Minerals, 2012). He turned his sights to the Kingdom of Tonga, the sponsoring state which had given Nautilus Minerals a foothold in the international waters of the Lau Basin, an ocean territory contested by the Republic of Fiji shouldering Tonga's border. Compared to courting trouble with Papua New Guinea over the Solwara 1 Project, the Tongan state appeared to be well-behaved friendly islanders; a flawed Western stereotype demarcating the cultural distinction between Melanesians and Polynesians.

Nautilus has a highly prospective ground position, which includes 19 identified prospects in Tonga, including the recent high grade discoveries in the $N E$ 
Lau Basin and a 410 million tonne inferred mineral resource in the central Pacific. (Nautilus Minerals, 2012).

Featured on the Government of Tonga website was a Tongan official from the Ministry of Lands and Environment supporting SOPAC's objective to train government bureaucrats at the five regional workshops. A general consensus seemed to have crystallised between the workshop provider and the Tongan state bureaucracy. Here, it was believed that the "negotiation skills" of Pacific Islanders were lacking, missing, and needing serious work.

I don't want to speak on behalf of all Pacific Islanders but I don't think that negotiation skills are something that Pacific Islanders are particularly good at. From my perspective Pacific Islanders are brought up to respect others and especially foreigners. With long-term management issues like deep sea minerals I think there can be a tendency to feel inferior in front of big companies that come with a lot of status, wealth and technical knowledge. (Ministry of Information and Communications, 2013).

"I think there can be a tendency to feel inferior" was the self-perpetuating marker of prejudice that rang out. The Tongan official signalled that an inferiority complex was not singly experienced at the contract negotiations table with "big companies" of "status, wealth and technical knowledge" (Ministry of Information and Communications, 2013). Inferiority had infected the political ideology of the Tongan state, incapacitating the government's ability to function unconstrained by this social epidemic. As a result, it became muddled up with the notion of respect where showing respectful behaviour towards foreigners and visitors was somehow misconstrued as inferiority. "To feel inferior" provided the sore point that could be easily picked at and manipulated by foreign experts on deep sea minerals to justify why they needed to train the Pacific Islanders to think, speak, and behave like them, like the people with superior knowledge and know-how.

On Radio Australia Tonga's Deputy Prime Minister, Samiu Vaipulu, repeated the David and Goliath parable that "big 
companies" coming at small "Pacific Island nations" set-off many "problems" for the government.

We need to train our people to negotiate and make legislation so that it should be a win-win situation; not only the big companies to win and not our people. We need to work together combined as Pacific Island nations, and to agree into how we are going to tackle these problems. We have to look at that as a group; as a group will be stronger instead of negotiating by each nation. (Ewart, 2013).

Vaipulu presented an answer: "We need to train our people" to negotiate contracts with mining companies and draft legislation. The Deputy Prime Minister's key message was that SOPAC's Deep Sea Minerals Project had the Government of Tonga's buy-in as the regional authority that would train their bureaucrats to perform the task. His sweeping references to "our people" and "these problems" did less to resolve the complexity of seabed mining on the regional stage, and more to highlight that in national polity, the Tongan state exercised an unequal power relationship over its citizens.

In this context, Samiu Vaipulu exemplified the nature of top-down talk from inside the Tongan public service to the people on the outside of its decision-making authority. "Our people" denotes government bureaucrats responsible for negotiating the state's mining contracts with companies. It is not a reference to the people, meaning the citizens of the state. "These problems" implies the shared experience of Pacific Island countries, small players struggling to gain the bargaining advantage at the contract negotiations table with mining company giants. There is no recognition that "these problems" could possibly mean that the people, the ordinary Tongan citizens, are in any way contesting the government's decision to formalise deep sea mineral mining as a state sponsor.

If there was public opposition to the Government of Tonga's investment in deep sea mineral mining as a business strategy to grow the country's economy, then perhaps the Deputy Prime Minister had overlooked it. The challenge to the Tongan state came from overseas Tongans, specifically Tongans who had received a liberal education in American, New Zealand, and Australian universities. 'Eseta Schaaf sparked off the discussion in diaspora, using social media to 
draw the attention of Tongans settled in Pacific Rim countries to what was happening back in their homeland. A graduate of the University of Utah, Schaaf published an opinion piece on a New Zealand Tongan website with a call-to-action headline: "Government of Tonga: Don't open up Tongan waters to deepsea mineral exploration" (Schaaf, 2013).

SOPAC's Deep Sea Minerals Project is selling the idea that mining will be a viable economic alternative for Pacific Island nations, but in reality, deep sea mineral mining is not a sustainable development option for indigenous peoples. Mining involves the transporting, stockpiling, trans-shipment and processing of mineral ores which will produce millions of tons of toxic wastes, all of which will occur close to remote coastal communities relying on a healthy sea for their diet and income. (Schaaf, 2013).

Schaaf generated support from the overseas Tongans she appealed to. Responses to her article concurred that the Government of Tonga was gambling the ocean's future, and risking environmental sustainability with their deep sea mining campaign (Vea, 2013).

Tonga is suffering enough from the effects of climate change and the government wants to entertain the thought of blasting holes in the seabed? There is nothing in the economic gambles the Tongan government have invested the people's money in of late that should give anyone any confidence whatsoever about this. (Vea, 2013).

Added to environmental risks, social memory was stirred. One respondent to Schaaf's article likened the aggressive business takeover of deep sea minerals by multinational corporations as the 21 st century return of 19th century European colonial expansion in the Pacific (Teu, 2013).

Of course it's nothing new for corrupt companies to take advantage of weakling Pacific Island countries, let alone what European nations have done in their past brutal colonization. Leave our waterfront and beaches clean so the poor islanders can fish; their only means of 
life sustenance. It's depleted enough already. (Teu, 2013).

Schaaf's opinion piece did not initiate dialogue with the Tongan state about the stakes involved in selling deep sea minerals to foreign companies with no guarantee that this is sustainable business. It did, however, go some way to highlighting the divergent stands adopted by the Tongan homeland in contrast to the diaspora. Tension persisted in home and away; that is, discord existed between the old country and its new settlements in the Pacific Rim countries of New Zealand, Australia, and the USA.

Notably, a consequence of migration was that overseas Tongans applied their collective experience of being an ethnic minority cohort in a Western, developed, and democratic country to Tonga. As a development strategy, this was not a straightforward adaptation. Tonga was not New Zealand, Australia, or the USA, and subsequently, homeland Tongans often took the well intentioned advice of their overseas counterparts as sio lalo, looking down on their developing country predicament with marginal understanding about the reality of living, working, surviving in Tonga.

\section{You don't live here}

It was during my January of 2013 trip to Tonga that Lord Ma'afu, the Minister for Lands and Environment, confided his cabinet was in agreement with mining contracts for deep sea mineral exploration and exploitation. Tenement areas both inside Tonga's EEZ, and outside the continental shelf in international waters had been exclusively leased by Nautilus Minerals Incorporated of Toronto in Canada, Korean Ocean Research and Development Institute (KORDI) of Ansan, Gyeonggi Province in South Korea, and Bluewater Metals Proprietary Limited of New South Wales in Australia. The Government of Tonga was motivated by cash returns for the country, the hint of millions in royalties if large mineral deposits were found.

We fought. Fiercely I attacked Ma'afu arguing that his decision to move with haste into an unknown industry was impulsive, not carefully measured (Brown Pulu, 2012). Prospecting sea minerals required heavy investment and high technology. There was no absolute certainty that mineral deposits worth billions actually existed 6,000 metres below sea 
level. It was environmentally perilous and legally complex to legislate customary ownership of the sea by the same principles as land. But companies attested there was money to made, enticing the poor islands of Tonga to ride a wing and a prayer, exterminate our ocean life for the promise of money. Put like that, the Tongan state was painted as the down-andout desperate-for-cash villain, indifferent to her people.

The Minister countered. Not by a ruthless argument like I had pitched, but rather, with a composed retort that marked the difference between our lived realities: "You don't live here, Teena." He was right. No matter how emotionally attached I was to this small island Kingdom, how entangled I was in the lives, toils, and sensitivities of loved ones, I did not speak as a Tongan citizen who stayed permanently without access to a developed country doorway. It was privilege that allowed me to be a hardnosed critic: I regularly boarded Air New Zealand's Wednesday morning flight from Auckland to Tonga, always returning to a comfortable life that did not stare at Third World poverty on the faces of people, especially children. I could afford to be critical. I did not have to live here.

For ordinary people living in Tonga, deep sea mineral companies exploring the Kingdom's ocean floor for hydrothermal vents that produce polymetallic nodules to excavate, at the cost of damaging the environment and marine life, was by no means topical. It did not make headlines with local news outlets. Tonga's media moguls, Kalafi Moala and Pesi Fonua, made no editorial fuss. It did not get airplay on Radio and Television Tonga. No locally organised petitions were submitted to the legislature, nor were constituency representatives to the House asked to raise it in parliament.

Not one letter of citizen complaint was addressed to Lord Ma'afu, the Minister for Lands and Environment, or to the head of government, the Prime Minister Lord Tu'ivakano. No organised protests, public objections, or newspaper letters to the editor about mining vessels docked at the Port of Nuku'alofa materialised. Nautilus Minerals Incorporated formed a subsidiary company and office in Tonga, and SOPAC ran its second regional workshop on deep sea minerals at Fa'onelua National Convention Centre without concern, question, apprehension, ever being raised.

But Tonga's silence on seabed mining was not how I had thought. Local Tongans had no less access than I, and overseas Tongans, to public information on environmental issues triggered from staging a development industry that is 
experimental not established. This was a small island developing state with 664,853 square kilometres of ocean territory constituting $7 \%$ of the world's coral reefs and $6 \%$ of the world's sea mountains. Tonga had 3,431 square kilometres of continental shelf. The Tongan state sponsored tenement areas in international waters it leased out to companies (University of British Columbia, 2013). Finding public information was no less restricted inside Tonga's border.

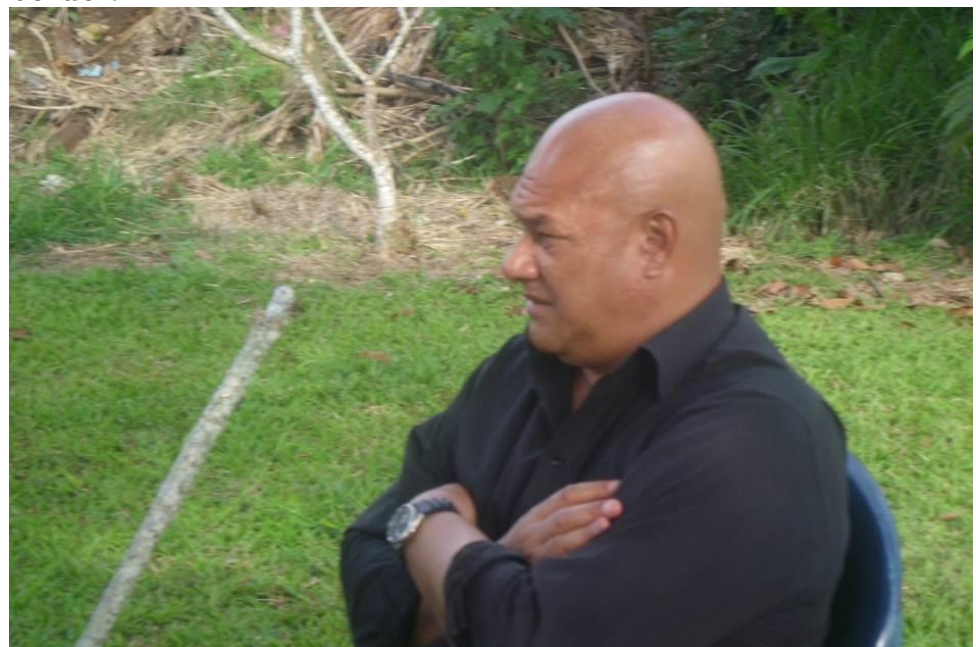

The Minister for Lands and Environment at the Government of Tonga, Lord Ma'afu, who is the traditional head of the Ha'a Havea Lahi and the noble of Vaini and Tokomololo.

The limitation rested in the perception of time. Arguing my environmental justice case to Lord Ma'afu, he cut through my First World hang-ups about his Third World country by a simple remark: "Tonga doesn't have time." He was alluding to climate change; his small coral homeland swallowed by the sea, slow torture, consumed inch-by-inch while he watched in vain. It confounded me how he reconciled two separate ministries, operating them as one, when their clashing development philosophies cancelled each other out. Lands had the geologists supporting deep sea mineral mining as the cash prize for Tonga. Environment had the conservationists promoting the protection of Tonga's biodiversity and fragile ecosystems. And here was the Honourable Minister for both 
sides, Lands and Environment, mitigating the political impact of a weak democratic state with opposing public policies. His role was to make sense of a discordant relationship where one had to give way - commercial mining versus safeguarding the environment.

I felt conflicted. But for Ma'afu, Tonga's development pathway was clear-cut in an ocean terrain. An ocean which scientists claimed suffered from severe "biodiversity loss" at being "overfished and under-protected" (Garrett, 2013); an entire water world on the "brink of catastrophic collapse" (Levitt, 2013). He lived here. I did not. He saw a way forward assuaging his country's intergeneration debt misery. I was caught in its density. He was willing to battle the odds. I preferred to theorise its consequences. If anything, our Tonga and New Zealand locations collided, sculpting the way we oriented deep sea minerals in two dissimilar meanings. Ma'afu saw possibility. I predicted unlikelihood.

\section{Afterthought}

The conversation between the Tongan state and its citizens on deep sea mineral mining is waiting to enter the public domain. Local media is the political climate gage that either assesses or stimulates a raft of opinions, questions, disputes, developments, of national importance. Tonga's new democratic arrangement would be worse for wear if the bill for a deep sea minerals act was deliberated in parliament before calling for public submissions. It would be constitutionally unsound, to say the very least, for the Government of Tonga short-cut their own system of transparency to push a law through the House of complete newness to the country.

If I had to be critical about one point, then it would be the get them before they get you psychology of doing deep sea mineral business. This is the corporate convention of bullying, badgering, and bargaining for control. A strategic tool of the old colonial powers, it represented an ideal of economic transaction, indoctrinating the horde of administrators, legislators, military forces, tinkers, and traders. These groups constituted the power and money brokers migrating to the Pacific Islands to discipline "the lazy Native" into the modern world system, and in the process, altering the social landscape and the local people's state of mind permanently (Brown Pulu, 2013). I know this by lived experience. I am the human 
product of a colonial trader. But for the most part, I am a Native on the short end of the stick getting given other people's development. 


\section{References}

AusAID. (2011). Australia's Mining for Development Initiative. Canberra, Australia: Australian Agency for International Development (AusAID), Pp. 1-24.

Bacon, K. (2000). An African Voice. The Atlantic, Atlantic Media Company, Washington DC, USA, August 2. Retrieved from

http:/ / www.theatlantic.com/magazine/archive/2000/08/an-africanvoice/306020/

Brooks, J. (1994). Interviews: Chinua Achebe, The Art of Fiction No. 139. The Paris Review, New York, USA. Retrieved from

http://www.theparisreview.org/interviews/1720/the-art-of-fiction-no139-chinua-achebe

Brown Pulu, T. (2012). Ma'afu's word is in the hills: What is a Noble's role in a democratised Tonga? Te Kaharoa: The e-Journal on Indigenous Pacific Issues, 5 (1): 138-208.

Brown Pulu, T. (2013). This Lazy Native's Quitting the Daytime Job. Going Home to the Village. Yeah Right. In Pacific Identities and WellBeing: Cross-Cultural Perspectives: Routledge Monographs in Mental Health, edited by M. Agee, T. McIntosh, P. Culbertson, and C. Makasiale. New York: Routledge, Pp. 66-86.

Ewart, R. (2013). Push to ensure Pacific nations gets the benefits of undersea mining opportunities. Australian Broadcasting Corporation: Radio Australia, Melbourne, Australia, March 20. Retrieved from

http://www.radioaustralia.net.au/international/radio/program/pacifi c-beat/push-to-ensure-pacific-nations-get-the-benefits-ofundersea-mining-opportunities/1104210

Foucault, M. (1972). The Archaeology of Knowledge. London: Tavistock Publications.

Foucault, M. (1980). Power/Knowledge: Selected Interviews and Other Writings 1972-1977, edited by C. Gordon. New York: Pantheon Books.

Garrett, J. (2013). New deal for oceans needed to stop biodiversity loss. AustralianBroadcasting Commission: Radio Australia, Melbourne, Australia, March 19. Retrieved from

http:// www.radioaustralia.net.au/pacific/radio/program/pacificbeat/new-deal-for-oceans-needed-to-stop-biodiversityloss/1103382

Hall, S. (1997). The Work of Representation. In Representation, Cultural Representations and Signifying Practices, edited by S. Hall. London: Sage Publications, Pp. 72-81.

Howard-Tokolahi, E. (2013). Personal Correspondence. San Francisco, USA, March 19.

Keen, K. (2013). Nautilus CEO opens up on PNG dispute. Mineweb: Uncompromising Independence, Nova Scotia, Canada, February 23. Retrieved from

http://www.mineweb.com/mineweb/content/en/minewebcanada?oid $=179127 \%$ sn $=$ Detail 
Levitt, T. (2013). Overfished and under-protected: Oceans on the brink of catastrophic collapse. CNN: International Edition, USA, March 22. Retrieved from

http://edition.cnn.com/2013/03/22/world/oceans-overfishingclimate-change/index.html

Matangi Tonga Online. (2013). Tonga Seabed Minerals Bill to go to parliament this year. Matangi Tonga Online, Nuku'alofa, Kingdom of Tonga, March 15. Retrieved from

http://matangitonga.to/2013/03/15/tonga-seabed-minerals-bill-goparliament-year

Menzies, S. (2013). Kingdom of Tonga to Host Regional Workshop on Law and Contract Negotiations for Deep Sea Minerals in the Pacific (March 11-15, 2013). SPC-EU Deep Sea Minerals Project: Secretariat of the Pacific Community Applied Geoscience and Technology Division (SOPAC), Suva, Fiji, March 4.

http://www.sopac.org/dsm/

Ministry of Information and Communications. (2013). Tonga hosts regional workshop on Deep Sea Minerals contracts negotiations. Tonga Government Portal, Nuku'alofa, Kingdom of Tonga, March 12. Retrieved from

http:/ / www.mic.gov.to/news-today/press-releases/4305-tonga-hostsregional-workshop-on-deep-sea-minerals-contracts-negotiations-

Nautilus Minerals Incorporated. (2012). Nautilus Minerals terminates equipment build for its Solwara 1 Project. Nautilus Minerals, Ontario, Canada, November 13. Retrieved from

http://www.nautilusminerals.com/s/MediaNewsReleases.asp?ReportID $=557207$

Schaaf, 'E. (2013). Government of Tonga: Don't open up Tongan waters to deepsea mineral exploration. New Zealand Kaniva Pacific, Auckland, New Zealand, March 13. Retrieved from

http://www.nzkanivapacific.co.nz/2013/03/13/government-of-tongadont-open-up-tongan-waters-to-deepsea-mineralexploitation/\#.UU1oK2n2_IU

Teu, A. (2013). Response to Government of Tonga: Don't open up Tongan waters to deepsea mineral exploration. New Zealand Kaniva Pacific, Auckland, New Zealand, March 22.

University of British Columbia. (2013). EEZ Waters of Tonga. Sea Around Us Project, The University of British Columbia, Vancouver, Canada, March 25. Retrieved from

http://www.seaaroundus.org/eez/776.aspx

Vea, 'E. (2013). Response to Government of Tonga: Don't open up Tongan waters to deepsea mineral exploration. New Zealand Kaniva Pacific, Auckland, New Zealand, March 14.

\section{Photographs}

Kolonga Reef, Kingdom of Tonga, Teena Brown Pulu, 2013

Fa'onelua National Convention Centre, Teena Brown Pulu, 2013

Fa'onelua National Convention Centre, Teena Brown Pulu, 2013

Fa'onelua National Convention Centre, Teena Brown Pulu, 2013 
Fa'onelua National Convention Centre, Teena Brown Pulu, 2013

Lord Ma'afu at Vaini, Kingdom of Tonga, Teena Brown Pulu, 2011

\section{Tongan glossary}

Sio Lalo Haughtily looking down on a person/people

Ta'ovala Hand-woven mat worn by Tongans

Palangi European, general reference to white person/people 